УДК 94(470)"19"

\title{
Г.О. Мациевский
}

\section{ГОСУДАРСТВО И КАЗАЧЕСТВО: ПОИСК ПУТЕЙ ВОЗРОЖДЕНИЯ}

\author{
Публикаиия подготовлена при финансовой поддержке РФФИ и Администраиии Краснодарского края \\ в рамках научного проекта № 16-11-23008.
}

\begin{abstract}
Рассматриваются основные направления и особенности политики государства по возрождению российского казачества в конце 1980-х - первой половине 1990-х гг. Делается вывод о том, что к концу рассматриваемого периода сложилось несколько подходов к логике его дальнейшего развития. Первый - возрождение казачества в качестве «народа» («культурноэтнической общности»), второй - в качестве «неосословия», военизированной структуры, предназначенной нести «государственную и иную службу».

Ключевые слова: современное казачество; возрождение казачества; этнос; сословие; государственная политика.
\end{abstract}

Более четверти века прошло со времени появления в нашей стране уникального общественно-политического и социокультурного явления - современного казачества. Пройдя путь от культурно-просветительских, фольклорно-этнографических обществ и военно-исторических клубов до общественных и некоммерческих организаций, принимая активное участие в политических, социальных, экономических процессах в различных регионах России, современное казачество продолжает оставаться явлением разноплановым, социально, политически и культурно неоднородным.

Согласно данным исследования, проведённого в июле 2008 г. Министерством регионального развития РФ, современное казачество определяется как «многокомпонентная структура, включающая в себя разнородные элементы, к которым относятся:

- представители разных топоэтнических и конфессиональных групп;

- прямые потомки казаков, служившие Российской империи и Советскому государству;

- граждане, идентифицирующие себя с казачеством из романтических, патриотических, экономических, политико-карьерных соображений;

- члены казачьих обществ, внесённых в государственный реестр;

- члены казачьих общественных объединений;

- члены традиционных объединений казаков (например, казаки-некрасовцы);

- члены неформальных общественных объединений;

- граждане, идентифицирующие себя с казачеством, но не вовлечённые в казачье движение» [1. С. 4].

Вопрос же путей и форм возрождения казачества в среде самих казаков продолжает оставаться открытым до сих пор. Однако данная статья будет посвящена прежде всего политике государственной власти в отношении казаков, так как именно власть играла и продолжает играть исключительную роль в определении места и роли казачества в современной российской действительности.

Сразу отметим, что история показывает достаточно наглядные примеры того, какую роль играло государство в жизни казачества. В течение XVIII-XIX вв. оно активно реформировало систему управления и организации казачьих сообществ, формировало новые, «служилые», казачьи войска, поддерживало и регулировало численный состав казачества, нередко включало в его состав представителей других наций и сословий, «оказачивало», «расказачивало», переселяло, распускало и переформировывало существовавшие казачьи войска [2]. В результате к началу XX в. казачество не представляло из себя этнического и вероисповедального монолита и развивалось как «полиэтническая, социокультурная сословно-служилая общность с преобладанием русского этнического компонента, с особыми формами сословной, войсковой, политической, социальной, региональной, культурной и бытовой организации, характеризующаяся поликонфессиональностью с определяющим доминированием православия не только как веры, но и как культурно-идеологической основы российской имперской государственности» [Там же. С. 103].

В конце 1980-х - начале 1990-х гг., с разрушением существовавшей национально-политической, социально-экономической, идеологической системы общества, начинают проявлять себя общественные силы, пытающиеся определить свой статус в новой действительности, объединиться, чтобы во времена всеобщего хаоса и неразберихи найти своё место в структуре новой государственности, просто выжить. По всей стране появляются неформальные объединения, группы, кружки, фонды и т.п. Число их к 1987 г. превышает уже 30 тысяч.

На заседании Политбюро ЦК КПСС 6 сентября 1989 г. принимается решение о создании группы политического анализа при ЦК КПСС, основными направлениями деятельности которой были определены: «комплексный анализ общественно-политической ситуации в стране; изучение идейно-политических позиций и социальных характеристик различных общественно-политических движений, действующих в стране, исследование расстановки политических сил», а также «прогнозирование возможных тенденций развития идеологической и политической ситуации...» [3. Л. 1]. Значение, которое Политбюро придавало созданию данной группы, характеризуют, в том числе, такие факты: штат группы определялся в 33 человека, при этом руководитель группы получал «права заведующего отделом ЦК КПСС», в подчинение группе передавались «система социологических исследований Академии общественных наук при ЦК КПСС с периферийной сетью на базе высших партийных школ, а также центров и групп изучения общественного мнения при 
ЦК компартиях союзных республик, крайкомах, обкомах и горкомах партии...» [Там же. Л. 2].

В конце февраля 1990 г. по стране прокатился ряд политических митингов и демонстраций в защиту «демократических преобразований», что заставило политическую власть страны констатировать: «...происходит радикализация общественного сознания, усиливается недоверие к официальным политическим структурам и органам управления, всё более жёсткий характер приобретает критика “партократии”, местного и центрального аппарата... Усиливаются центробежные тенденции в разных регионах страны...», а потому необходимы «анализ и прогнозирование общественнополитической ситуации, всестороннее изучение общественного мнения... Поддерживать контакты и связи с лидерами общественных движений и организаций, анализировать их программы и платформы...» [3. Л. 5-6]. Для реализации этих задач решением Политбюро ЦК КПСС от 29 марта 1990 г. в структуре аппарата ЦК КПСС создаётся Отдел по работе с общественнополитическими организациями, возглавляет который теперь один из секретарей ЦК КПСС.

В этих условиях всё более активно начинает заявлять о себе движение за возрождение казачества. По данным Института этнологии и антропологии Российской академии наук на начало 1990-х гг. в исторических казачьих областях (Дон, Терек, Кубань) потомки казаков по прямой линии составляли 10-15\% населения, в Сибири и на Дальнем Востоке - около 1-5\% населения. Всего же причисляли себя к потомкам казаков до 5 млн человек [4. С. 113], проживающих на территории России, т.е. около $3 \%$ от всего населения страны.

Мощным импульсом активизации политической жизни казачества стало принятие Закона РСФСР № 1107-1 «О реабилитации репрессированных народов» от 26 апреля 1991 г., который провозглашал отмену всех незаконных актов, принятых в отношении всех репрессированных народов и «иных исторически сложившихся культурно-этнических общностей людей, например казачества» [5. Ст. 572], и определял механизм их реабилитации. Статьи 3 и 11 Закона гласили, что «реабилитация репрессированных народов означает признание и осуществление их права на восстановление территориальной целостности, существовавшей до антиконституционной политики насильственного перекраивания границ, на восстановление национально-государственных образований, сложившихся до их упразднения, а также на возмещение ущерба, причинённого государством», а «культурная реабилитация репрессированных народов предусматривает осуществление комплекса мероприятий по восстановлению их духовного наследия и удовлетворению культурных потребностей. Это означает также признание за репрессированными народами права на возвращение прежних исторических названий населённым пунктам и местностям, незаконно отторгнутым у них в годы советской власти» [Там же]. Данный Закон предполагал рассмотрение казачества в качестве «репрессированной» «культурно-этнической общности» наряду с чеченцами, ингушами, крымскими татарами и др.
В этот же день было принято Постановление ВС РСФСР № 1108-1 «О порядке введения в действие Закона РСФСР “О реабилитации репрессированных народов”» [Там же. Ст. 573], а 17 мая Распоряжение Совета министров РСФСР № 468-р, в которых уточнялись и детализировались действия различных органов власти по реализации Закона РСФСР № 1107-1.

Таким образом, государственной властью закладывалась одна из ведущих линий дальнейшего развития казачьего движения - возрождение его в качестве «культурно-этнической общности», репрессированного «народа». Данный статус ставил казачество в положение «униженных и оскорблённых» советским государством, что позволяло использовать его протестный потенциал в деле реформирования существующего строя. В то же время признание за казаками права считаться особым «народом» (может быть, даже противопоставленным русскому народу как государствообразующему) могло стать ещё одним фактором внутреннего «раскола» как самого русского народа, так и всего российского общества.

23 мая 1991 г. для Секретариата ЦК КПСС Отделом ЦК КПСС по связям с общественно-политическими организациями в ответ на Обращение бюро Ростовского обкома КПСС, в котором ставился «вопрос о принятии ЦК КПСС постановления о политической и гражданской реабилитации казачества» [6. Л. 6], была подготовлена записка (Ст-1377c) за подписью заместителя заведующего Отделом И. Знаменского, в которой давалась характеристика «состояния и тенденций нынешнего развития движения казачества» [Там же].

В записке, в частности, констатировалось, что, «начавшись в 1987 г., за короткое время оно [движение казачества] выросло в значительную общественно-политическую силу, объединяющую, по оценкам её руководителей, несколько сот тысяч человек. По целому ряду принципиальных вопросов общественного развития движение занимает здравую, конструктивную позицию, значительное число участников и атаманов являются членами КПСС. В ряде регионов страны деятельность организаций Союза казаков находит поддержку со стороны населения, партийных и советских органов» [Там же].

В то же время составители записки отмечали, что «сложность и неоднозначность проблем истории и современного состояния казачества, политических, экономических и социальных положений, выдвигаемых в программных документах Союза казаков, требуют всестороннего анализа...» [Там же. Л. 6-7].

К основным проблемам были отнесены: «...необходимость определить правомерность использования понятия “народ” применительно к казачеству, отношение к требованиям о создании казачьих представительств в высших органах власти СССР и республик, признание права на самоуправление и экономическую самостоятельность бывших казачьих территорий, о формировании отдельных подразделений в Советской Армии и погранвойсках...» [Там же. Л. 7].

Важность решения данных проблем объяснялась «нарастанием социальной напряжённости в связи с активизацией стихийного движения за возрождение 
казачества, что уже привело к острым межнациональным конфликтам и человеческим жертвам», при этом подчёркивалось, что «дополнительным катализатором этих процессов может стать принятый в апреле с.г. Закон РСФСР “О реабилитации репрессированных народов”, узаконивший право казаков на восстановление целостности административно-территориальных границ, существовавших до их изменения» [6. Л. 7]. В связи с вышеизложенным, авторы записки предлагали «рассмотреть вопрос о принятии постановления об отношении к казачеству на Секретариате ЦК КПСС с целью последующего выхода в Верховный Совет СССР с законодательной инициативой» и «поручить отделам ЦК КПСС: по связям с общественно-политическими организациями, гуманитарному, по законодательным инициативам и правовым вопросам, национальной политике принять участие в работе по подготовке данного документа» [Там же. Л. 8].

Растущее внимание, которое стало уделяться «казачьему вопросу», характеризует и тот факт, что контролировать его было поручено заместителю Генерального секретаря ЦК КПСС В.А. Ивашко. 27 мая 1991 г. за подписью В. Ивашко в адрес Секретариата ЦК КПСС была направлена рукописная записка (К № 1377), из которой явствует, что к тому времени в ЦК КПСС по «казачьему вопросу» «параллельно ходит три документа: 1) письмо т. Шолохова, к которому присоединены... некоторые архивные документы..; 2) записка Отдела по национальной политике «О законе РСФСР “О реабилитации репрессированных народов”»; 3) настоящий документ...» [Там же. Л. 5].

В записке Отдела по национальной политике ЦК КПСС «О некоторых проблемах, связанных с реабилитацией репрессированных народов» говорилось о тех серьёзных негативных последствиях, которые может вызвать и уже вызвал Закон «О реабилитации репрессированных народов» в сфере межнациональных отношений в многонациональных регионах РСФСР и за её пределами [7. Л. 2-7]. В частности, давался анализ ситуаций, сложившихся в Бурятии, Северо-Осетинской АССР, Чечено-Ингушской республике, Дагестане, Калмыкии, в районах компактного проживания немцев Поволжья. Однако основное внимание уделялось прежде всего казачеству, так как оно было представлено в различных регионах.

В эти же дни в адрес заместителя Генсекретаря ЦК КПСС В.А. Ивашко было направлено письмо, подписанное секретарями ЦК КПСС А. Дзасоховым, А. Гиренко и В. Купцовым, в котором отмечалось, что «вопрос, связанный с возрождением казачества, уже сейчас, а в перспективе особенно, приобретает чрезвычайно важное общественно-политическое значение», в связи с чем «для выработки общепартийной и государственной политики в этом вопросе» предлагалось «привлечь учёных-специалистов из Института этнологии и этнографии АН СССР, Института теории и истории социализма ЦК КПСС, АОН ЦК КПСС, ЦКК КПСС, а также запросить необходимые материалы КГБ СССР, соответствующих архивов» и «создать группу в составе: т.т. Дзасохова А.С. - председатель, Гиренко А.Н., Купцов В.А., Мохов Е.Н., Бабичев В.С., Дегтярев А.Я., Михайлов В.А., Зараменский И.А.,
Антонович И.И., Суслин В.Т. Поручить группе подготовить в течение 2 месяцев соответствующие предложения» [6. Л. 1].

7 июня 1991 г. в целях реализации распоряжений Секретариата ЦК КПСС и положений Закона «О peaбилитации репрессированных народов», Распоряжением Первого заместителя Председателя Верховного Совета РСФСР № 1374-I «О создании рабочей группы по подготовке проекта нормативного акта о политической реабилитации казачества» была создана такая рабочая группа. Интересно, что в группу вошли специалисты Госкомнаца, Комиссии по национальногосударственному устройству и межнациональным отношениям Совета Национальностей Верховного Совета РСФСР, представитель Союза казаков России (Ю.А. Галушкин) и два профессиональных историка, специализирующихся на истории казачества (Н.Ф. Бугай, А.И. Козлов). Распоряжением устанавливался и срок готовности проекта нормативного акта для рассмотрения в Верховном Совете РСФСР 1 сентября 1991 г. Данный состав рабочей группы может свидетельствовать о том, что власть продолжала рассматривать проблему «политической реабилитации» и будущности казачества сквозь призму, прежде всего, национального возрождения.

В августовском номере «Известий ЦК КПСС» за 1991 г., в статье старшего референта Отдела ЦК КПСС по связям с общественно-политическими организациями С. Павловского, заявлялась «линия партии» в отношении казачества. В статье отмечалось, что сильной и одновременно слабой стороной движения являются его динамичность и растущая массовость. При этом делался прогноз, что в перспективе самая серьёзная опасность для казачьего движения может быть в том, что «темпы роста его массовости опережают темпы консолидации» [8. С. 135]. В то же время констатировалось, что движение существует и, скорее всего, будет развиваться, оказывая всё большее воздействие на общественно-политическую ситуацию в стране и регионах. В связи с этим давалась установка ЦК КПСС на взаимодействие с казачьими организациями: «...представляется перспективной политика тех советских и партийных органов, которые, не затушёвывая противоречий, идут на контакты с казачьими организациями, находят взаимоприемлемые решения в интересах стабилизации внутриполитической обстановки в стране» [Там же]. В это же время в некоторых регионах, прежде всего на Кубани и Дону, в партийных организациях появляются инструкции по работе с казачеством, в которых ставится цель - входить в объединения казаков и возглавлять их.

Последующие события, связанные с августовским «путчем» ГКЧП, прекращением деятельности ЦК КПСС и развалом СССР, приостановили планируемую работу, однако уже в 1992 г. в составе Института этнологии и антропологии РАН создаётся Консультативный совет по проблемам возрождения российского казачества, начинает работать «Группа по изучению казачества при Координационно-методическом центре прикладной этнографии» и «Проблемная группа Консультативного совета по проблемам возрождения российского казачества». 
На следующий день после подписания «Беловежского соглашения», «распустившего» СССР и «образовавшего» СНГ, 9 декабря 1991 г., Президент РСФСР Б. Ельцин подписывает Распоряжение № 113-рп «О создании комиссии по подготовке проекта Закона РСФСР “О реабилитации казачества"», что вновь стимулировало рост политической активности казаков. Согласно распоряжению, руководителю Администрации Президента РСФСР Ю.В. Петрову предписывалось «обеспечить Комиссию необходимым помещением, средствами связи, оргтехникой, выделить средства для привлечения специалистов и экспертов в сумме 30 тыс. рублей» [9. Ст. 1819].

Постепенно казачество всё более активно начинает заявлять о себе как о самостоятельной силе, имеющей свои этнокультурные, экономические и даже политические интересы и приоритеты [10]. В условиях необходимости формирования новых основ государственности власть начинает выстраивать иную логику дальнейшего развития новой казачьей общности. Её протестный потенциал теперь уже не так актуален и, более того, вовсе не нужен. С целью придания движению за возрождение казачества «целесообразности» и нужной «направленности» Главнокомандующий вооружёнными силами Содружества независимых государств маршал Е. Шапошников направляет в адрес Президента РФ Б. Ельцина Письмо № 312/2/1 от 11 января 1992 г. «О проблеме возрождения Казачества в России», в котором констатирует, что «в настоящее время движение казаков за возрождение Казачества в России носит неуправляемый характер» и «может принять негативную направленность» [11. Л. 1-2]. В связи с этим, по мнению Е. Шапошникова, необходимо «совместно с Государственным комитетом Российской Федерации по обороне и безопасности подготовить и провести в январе-феврале встречу с руководством казаков России», на которой «рассмотреть вопросы о снятии юридических ограничений, препятствующих возрождению Казачества в России, о возможности создания казачьих соединений и частей в составе Вооружённых Сил, дислоцирующихся на территории России, а также регулярных и иррегулярных частей в составе внутренних войск Российской Федерации, о создании военных учебных заведений для подготовки кадров для казачьих соединений и частей, о возможном порядке их материального обеспечения, о проведении совместных учебно-строевых мероприятий...» [Там же. Л. 2]. Таким образом, как явствует из приведённого Письма, одним из направлений дальнейшего развития казачьего движения представители власти готовы поддерживать, в том числе, воинскую (сословную) службу.

Однако у государства ещё нет однозначной и бесспорной позиции по поводу будущего казачества. В январе 1992 г. в составе Комиссии Совета Национальностей по международным отношениям и национально-государственному устройству России создаётся специальная Комиссия по репрессированным депортированным народам под председательством члена Президиума Верховного Совета РФ А.В. Аникеева, в которую входит и подкомиссия по казачеству. Направление возрождения казачества в качестве «репрессированной» «культурно-этнической общности», заложенное Законом РСФСР № 1107-1 «О реабилитации репрессированных народов» от 26 апреля 1991 г., также продолжает развиваться.

Стремясь повысить свой авторитет в казачьем движении, Правительство РФ публикует 24 марта 1992 г. Распоряжение № 545-Р об образовании Комиссии для выработки проекта Закона РФ «О реабилитации казачества», которую возглавляет заместитель Председателя Правительства РФ С. Шахрай. От казачества в Комиссию входят: атаман Союза казаков Урала и Поволжья Б. Гусев, атаман Оренбургского казачьего войска В. Косянов, член правления Союза казаков В. Держиев, атаман Союза казаков А. Мартынов, атаман Кубанской казачьей Рады В. Громов, кошевой атаман Союза казаков Области Войска Донского А. Мрыхин и атаман Ставропольского краевого Союза казаков П. Федосов. Распоряжением № 546-Р в этот же день создаётся рабочая группа для выработки проекта Закона РФ «О реабилитации казачества» и соответствующих рекомендаций Президенту РФ, в которую входят четыре представителя от казачества: помощник атамана Союза казаков С.Н. Смирнов, помощник атамана Кубанской казачьей Рады Ю.Н. Загудаев, председатель земельной комиссии Союза казаков В.С. Шамаев и представитель Союза казаков А.С. Калтахчян. К рассмотрению проблем, связанных с определением места и роли казачества в современном обществе, начинают всё чаще привлекать представителей научных кругов, организуются дискуссии в научных институтах, проходит круглый стол в Горбачёв-Фонде. Однако все обсуждения в конечном счете сводились к одному - спору о том, что есть казачество - народ или сословие, а значит, подпадает ли казачество под Закон РСФСР «О реабилитации репрессированных народов» или нет.

Важным государственным документом, конституирующим перспективы развития казачьего движения, стал Указ Президента РФ Б. Ельцина от 15 июня 1992 г. № 632 «О мерах по реализации Закона Российской Федерации “О реабилитации репрессированных народов” в отношении казачества» [12. Ст. 1429]. Пункт 3 Указа устанавливал, что казаками считаются граждане, относящие себя к прямым потомкам казаков и выразившие желание совместно восстанавливать и развивать формы хозяйствования, культуры, быта и участвовать в несении государственной службы, а также граждане, в установленном порядке добровольно вступившие в казаки. И хотя преамбула Указа подтверждала культурно-этнический статус казачества, положение о том, что в казачество возможно «добровольное вступление», фактически отрицало этнический характер движения, так как «вступить» в народ нельзя. Необходимым и достаточным условием для причисления к казачеству провозглашалось лишь желание быть казаком и участие в совместном хозяйствовании и несении государственной службы. По всей видимости, этим Указом государственная власть в лице Президента РФ заявляла о своём желании способствовать развитию казачьего движения, постепенно вводя его в русло государственной структуры на правах сословной военно-экономической организации, хотя пункт 2 и провозглашал 
отказ от «возврата к каким-либо сословным привилегиям» [Там же]. В то же время в Указе не формулировалось конкретных мер по реализации Закона РСФСР от 26 апреля 1991 г. № 1107-1 «О реабилитации репрессированных народов», что, в общем-то, предполагалось, исходя из его названия. Пункт 1 не отменял все репрессивные акты в отношении казачества, а лишь осуждал «проводившуюся партийногосударственную политику репрессий, произвола и беззакония в отношении казачества и его отдельных представителей» [12. Ст. 1429].

Постановление «О реабилитации казачества» в основном повторяло положения, изложенные в Законах «О реабилитации репрессированных народов» от 26 апреля 1991 г. и «О местном самоуправлении в Российской Федерации» от 6 июля 1991 г., в Указе Президента РФ «О мерах по реализации Закона Российской Федерации “О реабилитации репрессированных народов” в отношении казачества» от 15 июня 1992 г. Однако анализ документов позволяет утверждать, что казачество с 1992 г. всё чаще начинает рассматриваться государственной властью не только как «разрушающая», но и как «созидающая» сила, с помощью которой можно было бы закрепить и дальше развивать политику реформ. В то же время становится и более понятной логика государственной власти по возрождению казачества - рассмотрение его как социальной группы, некого «неосословия», призванного нести лишь государственную или связанную с ней службу за определённые привилегии, например за землю или налоговые послабления.

В октябре 1992 г. при Правительстве РФ была создана рабочая группа по изучению казачества во главе с секретарём Совета Безопасности Ю. Скоковым, в которую вошли также атаман Союза казаков России А. Мартынов и атаман ВКВ (ККР) В. Громов.

Следующий Указ Президента Российской Федерации № 341 от 15 марта 1993 г. «О реформировании военных структур, пограничных и внутренних войск на территории Северо-Кавказского региона и государственной поддержке казачества» определял военные аспекты возрождения казачества и стратегические линии поведения институтов государственной власти по отношению к казачьему движению. Согласно Указу, члены казачьих обществ имели право проходить военную службу в казачьих соединениях и частях Вооруженных Сил РФ, пограничных войсках, казачьих моторизованных воинских частях и частях оперативного назначения внутренних войск в соответствии с Законом Российской Федерации «О воинской обязанности и военной службе». В связи с этим Министерству обороны, Министерству безопасности и Министерству внутренних дел Российской Федерации предписывалось до 1 апреля текущего года утвердить перечень казачьих соединений и частей в «рамках существующих структур и численности Вооруженных Сил Российской Федерации, пограничных... и внутренних войск», внести до 1 мая 1993 г. предложения по присвоению казачьим соединениям и частям традиционных казачьих наименований и дополнению действующих законодательных актов нормами, предусматривающих учреждение казачьих во- инских званий, парадной формы одежды и отличительных знаков [13. Ст. 993]. Также предполагалось в аппаратах силовых министерств создать структуры по делам казачества. На территориях компактного проживания казаков планировалось образование при органах общественного местного самоуправления добровольных невоенизированных структур для работы «по патриотическому и интернациональному воспитанию казаков, подготовке их к защите Отечества, развития технических и прикладных видов спорта, а также для участия в мероприятиях гражданской и территориальной обороны, ликвидации последствий стихийных бедствий и чрезвычайных ситуаций и оказании помощи пострадавшим» [13. Ст. 993].

Данный Указ вызвал много споров как среди казаков, так и представителей власти. Так, Председатель Совета национальностей Верховного Совета РФ Р. Абдулатипов при обсуждении вопроса «О неотложных мерах по сохранению конституционного строя Российской Федерации» на IX (внеочередном) Съезде народных депутатов Российской Федерации прокомментировал его следующим образом: «Названный указ оскорбителен прежде всего для казачества, потому что в конце XX в. роль этого народа, этой общности, фактически сводится $к$ полицейским, жандармским функциям (здесь и далее курсив мой. Г.М.)... Подобные действия разрушают российскую государственность. Я должен сказать здесь, я с величайшим уважением отношусь к казачеству, поддерживаю его реабилитацию, но ни один народ Кавказа, ни один другой народ России не согласится жить под нагайкой казака. Мы достаточно воевали с казаками в историческом прошлом, но сегодня мы соседи, хотим жить в братстве, и нечего нас науськивать друг на друга. Я обращаюсь сегодня к Президенту... с просьбой приостановить действие указа до дополнительных консультаций с субъектами Федерации и лидерами национальных движений Северного Кавказа. Иначе контролировать ситуацию в регионе будет трудно» [14].

В то же время Р. Абдулатиповым в адрес Б. Ельцина было направлено Письмо № 6-205 от 23 марта 1993 г., в котором также заявлялось: «Прежде всего не может не настораживать, что меры государственной поддержки казачества даются в нём (Указе № 341 от 15.03.1993 г.) преимущественно “в связке” с реформой военных структур и фактически нацелены на превращение культурно-этнической общности в соцзиальный строй, поставляюший особые военные формирования...» [15. Л. 23-24]. В ответ для Совета министров - Правительства Российской Федерации была подготовлена записка за подписью заместителя председателя Госкомфедерации В. Михайлова, в которой сообщалось, что «по материалам письма... сотрудниками Госкомфедерации России совместно с работниками Совета Безопасности была проведена экспертиза оценки критических замечаний по ряду положений Указа Президента Российской Федерации № 341 от 15 марта 1993 г. ....На состоявшемся 1415 сентября заседании Конституционного Суда Указ № 341 был признан соответствующим Конституции РФ» [Там же. Л. 25]. 
Таким образом, движение за возрождение казачества постепенно и целенаправленно трансформировалось государством: из малопредсказуемой самостоятельной общественно-политической силы, имеющей свои политические цели и задачи, в «военногосударственно-добровольно-общественную» организацию по образцу ДОСААФ или местных комитетов по гражданской обороне. В качестве «сословной привилегии» для казаков, проходящих военную службу, планировалось разработать Положение об «особом режиме пользования землями». Для облегчения управления казачьим движением Указ хотя и предусматривал участие казачества в органах местного самоуправления, вместе с тем предполагал «ответственность атаманов и членов казачьих обществ за невыполнение обязательств перед государством» [13. Ст. 993].

Летом 1993 г. в Департаменте по делам казачества Государственного комитета РФ по национальной политике под руководством А.С. Лагутина и в Российской академии управления была активизирована работа по созданию Комплексной государственной программы поэтапного экономического и культурного возрождения казачества, которая должна была быть разработана до 1 января 1993 г. в соответствии с Указом Президента РФ от 15 июня 1992 г. № 632 «О мерах по реализации Закона Российской Федерации “О реабилитации репрессированных народов” в отношении казачества» и Постановлением Верховного Совета РФ от 16 июля 1992 г. № 3321-I. В июне 1993 г. Российской академией управления, при участии заместителя председателя Госкомфедерации В.А. Михайлова, были подготовлены «предварительные предложения» по Комплексной государственной программе «Возрождение социально-экономических, культурных и духовных традиций жизнедеятельности казачества» [16. Л. 103-107]. Констатируя, что «на сегодняшний день созданы 13 казачьих войск... 63 землячества, которые объединяют 6 миллионов казаков, проживающих как в городах (80\%), так и в сельской местности, станицах $(20 \%) \ldots »$ [Там же. Л. 104], разработчики Программы определяли, что её «целью... является определение комплекса мер и разработка пакета документов, направленных на управление движением казачества, возрождением его экономических, культурных, духовных традиций и форм самоуправления (не допуская вместе с тем возврата к каким-либо сословным привилегиям...)» [Там же. Л. 105]. В центре разработки программы должны были находиться следующие проблемы: «...выяснение исходных концептуальных “вещей”: что такое казачество как общность, что значит возрождение казачества, какие традиции следует возрождать и как это делать...» [Там же]. При этом планировалось реализовать данную Программу в течение июля 1993 - декабря 1994 г., а на финансирование «1-го этапа работы (июль - декабрь 1993 г.)» выделить 100 млн рублей [Там же. Л. 107].

В июне 1993 г. министром по делам национальностей и региональной политики С. Шахраем в адрес Президента РФ Б. Ельцина было направлено письмо, посвящённое анализу проблем казачества. По мнению С. Шахрая, «российское казачье движение стало серьёзной общественной силой, требующей незамедли- тельного организационного оформления. Ввиду отсутствия единого, централизованного управления в нём отмечаются определённые негативные тенденции, которые могут быть использованы как в ущерб коренным интересам идеи возрождения казачества, так и в ущерб делу укрепления Российской государственности» [15. Л. 95]. А потому «в деле возрождения казачества самыми принципиальными проблемами следует считать восстановление традиционных форм казачьего землевладения и землепользования, восстановления казачьего самоуправления и государственной службы» [Там же. Л. 96]. В то же время «центральным вопросом работы в казачьем движении на этапе его организационного оформления», как отмечал С. Шахрай, «следует считать преодоление раскола в казачьем движении, объединение его разрозненных действий в единое русло с опорой на позитивный потенциал державности и целостности Российского государства» [Там же].

Разработка Комплексной государственной программы поэтапного экономического и культурного возрождения российского казачества поручается теперь Институту экономики РАН, где была создана группа из специалистов и представителей казачества под руководством Д. Карпухина. На данную работу выделялось почти 54 млн руб., но результаты её не были особо продуктивными [17. С. 85-86]. Тем не менее рабочая концепция программы принимается за основу на III Большом круге Союза казаков [18. Л. 43, 53], который проходил 8-10 октября 1993 г., Третий вариант Комплексной программы [19. Л. 29-74], представленный руководителем творческого коллектива по разработке программы Д. Карпухиным 1820 декабря на Всероссийском совещании по проблемам возрождения экономики и культуры казачества, проводимом Институтом экономики РАН, Госкомфедерацией, Союзом казаков и Союзом казачьих войск России, был «одобрен в основном», как говорилось в «Резолюции» [Там же. Л. 16].

В своём вступительном слове представитель Госкомфедерации А.С. Лагутин отмечал, что «по оценкам российских и зарубежных экспертов от 2 до 25 млн человек относят себя к казакам. Это колоссальная сила...», и «сейчас казаки уже являются гарантом стабильности в некоторых регионах нашей страны...» [Там же. Л. 4]. По мнению Д. Карпухина, «предусмотренные в программе мероприятия будут иметь успех, если только будет соблюдён комплексный триединый характер возрождения. Первое - воинская служба, а из Минобороны пришло известие, что её в программу включать не надо, но тогда всё зависает. Самый сложный вопрос - территориальное возрождение. Уже давно пора и необходимо создать комиссии по казачеству при всех важнейших ведомствах, не только при Госкомфедерации...» [Там же. Л. 5]. Однако данная программа не добавляла ничего существенно нового к сложившимся подходам в государственной политике в отношении современных казаков.

Таким образом, можно констатировать, что к середине 1990-х гг. фактически завершился этап определения политики государства в отношении казачества и сложилось несколько подходов к политике его возрождения и дальнейшего развития. Первый - возрож- 
дение казачества в качестве «народа» (субэтноса, «культурно-этнической общности»), второй - в качестве некого «неосословия», военной силы, военизированной структуры, предназначенной нести «государ- ственную и иную службу». К концу рассматриваемого периода преобладающим и основным стал второй подход, предопределивший специфику государственной политики на последующие годы.

\section{ЛИТЕРАТУРА}

1. Современное российское казачество: политический, социальный, экономический портрет; анализ тенденций и прогноз развития государственной службы российского казачества : сб. материалов по результатам социол. исследования / Ефанова О.А., Шишова Ж.А., Соклаков А.Ю. и др. М., 2008. 48 с.

2. Мациевский Г.О. Особенности социально-демографического облика казачества в конце XIX - начале XX в. // Научные ведомости Белгородского государственного университета. Серия: История. Политология. Экономика. Информатика. 2013. № 1. С. 97-103.

3. Российский государственный архив новейшей истории (РГАНИ). Ф. 89. Оп. 9. Д. 29.

4. Казаки России: прошлое, настоящее, будущее. М., 1992. 131 с.

5. Ведомости Совета народных депутатов и Верховного Совета РСФСР (Ведомости СНД и ВС РСФСР). 1991. № 18.

6. РГАНИ. Ф. 89. ОП. 21. Д. 71.

7. РГАНИ. Ф. 89. ОП. 5. Д. 21.

8. Павловский С.В. Возрождение казачества: пути и проблемы // Известия ЦК КПСС. 1991. № 8 (319). С. $133-135$.

9. Ведомости Совета народных депутатов и Верховного Совета РФ (Ведомости СНД и ВС РФ). 1991. № 51.

10. Баранов А.В. Роль этнополитических мифов в конструировании идентичности казачества // История и современность. 2014. № 1. С. 6986.

11. Государственный архив Российской Федерации (ГАРФ). Ф. 10144. Оп. 1. Д. 27.

12. Ведомости СНД и ВС РФ. 25.06.92. № 25.

13. Собрание актов Президента и Правительства РФ. 1993. № 12

14. Девятый (внеочередной) съезд народных депутатов Российской Федерации. Бюллетень. № 3, 27 марта 1993. М. : Изд. Верховного Совета Российской Федерации, 1993.

15. ГАРФ. Ф. 10121. Оп. 1. Д. 121

16. ГАРФ. Ф. 10121. Оп. 1. Д. 120.

17. Таболина Т.В. Казаки: драма возрождения. 1980-1990-е годы. М., 1999.

18. ГАРФ. Ф. 10144. Оп. 1. Д. 35.

19. ГАРФ, Ф. 10144. Оп. 1. Д. 36.

Статья представлена научной редакцией «История» 22 августа 2017 г.

THE STATE AND THE COSSACKS: SEARCHING FOR WAYS OF REVIVAL

Vestnik Tomskogo gosudarstvennogo universiteta - Tomsk State University Journal, 2017, 424, 97-104. DOI: $10.17223 / 15617793 / 424 / 13$

German O. Matsievsky, Krasnodar State Institute of Culture (Krasnodar, Russian Federation). E-mail: matsievski2004@mail.ru Keywords: modern Cossacks; revival of Cossacks; ethnicity; neoclass; state policy.

The object of the study is the state policy concerning the modern Russian Cossacks. The chronological framework is the late 1980s to early 1990s. The aim of the study is to analyze the main directions of the state policy on the revival of the Cossacks using a large number of documents and contemporary records. At the turn of the 1990s the Soviet state collapsed, and a crisis began. Different social groups were beginning to take an active part in the state life. They were looking for their place in the new society. Cossack organizations can be included in these groups. Cossacks appeared in different regions of the country. They wanted to participate in the social and cultural, economic and political life of the society. There were about 5 million Cossacks in Russia. So the government had to normalize social relations with the Cossacks. Besides it had to take into account the history of relations between the state and the Cossacks. Just before the disintegration of the USSR, the authorities put one of the main lines in revival of the Cossacks as a "cultural and ethnic community" which the Soviet government repressed, it was done to use their protest potential for reforming the socialist system. After the collapse of the USSR, when the new basis of the Russian state was forming, the authorities began a new policy for the Cossacks development, as the protest potential was no longer needed. In order to give the Cossacks "proper" development, its military and public service was wanted in exchange for some privileges (land owning, tax benefits, etc.). In places where the Cossacks were numerous, it was planned to create non-military structures for organizing patriotic and international education, for preparing youth to protect the Homeland, to develop applied and technical sports, to participate in the natural disasters management, in civil and territorial defense measures like DOSAAF or military patriotic clubs. This logic can also be seen as an attempt to bring the Cossacks revival under control by turning it into a "neoclass" structure. As a result of the research, it is concluded that during the period under review the state policy towards the development of the Cossacks has gradually changed from its revival as a "nation" ("cultural-ethnic community") to its revival as a "neoclass" structure, a militarized structure intended to fulfill "state and other service" and controlled by the government.

\section{REFERENCES}

1. Efanova, O.A. et al. (2008) Sovremennoe rossiyskoe kazachestvo: politicheskiy, sotsial'nyy, ekonomicheskiy portret; analiz tendentsiy i prognoz razvitiya gosudarstvennoy sluzhby rossiyskogo kazachestva: sb. materialov po rezul'tatam sotsiol. issledovaniya [Modern Russian Cossacks: political, social, economic portrait; the analysis of tendencies and the forecast of development of public service of the Russian Cossacks: materials by the results of sociological research]. Moscow.

2. Matsievskiy, G.O. (2013) Osobennosti sotsial'no-demograficheskogo oblika kazachestva v kontse XIX - nachale XX vv. [Features of the sociodemographic appearance of the Cossacks in the late 19th - early 20th centuries]. Nauchnye vedomosti Belgorodskogo gosudarstvennogo universiteta. Seriya: Istoriya. Politologiya. Ekonomika. Informatika. 1. pp. 97-103.

3. Russian State Archive of Modern History (RGANI). Fund 89. List 9. File 29. (In Russian).

4. Tishkov, V.A. (ed.) (1992) Kazaki Rossii: proshloe, nastoyashchee, budushchee [Cossacks of Russia: past, present, future]. Moscow: IEA RAS.

5. Vedomosti Soveta narodnykh deputatov i Verkhovnogo Soveta RSFSR (Vedomosti SND i VS RSFSR). (1991). 18. 
6. Russian State Archive of Modern History (RGANI). Fund 89. List 21. File 71. (In Russian).

7. Russian State Archive of Modern History (RGANI). Fund 89. List 5. File 21. (In Russian).

8. Pavlovskiy, S.V. (1991) Vozrozhdenie kazachestva: puti i problemy [Revival of the Cossacks: ways and problems]. Izvestiya TsK KPSS. 8 (319). pp. 133-135.

9. Vedomosti Soveta narodnykh deputatov i Verkhovnogo Soveta RF (Vedomosti SND i VS RF). (1991). 51.

10. Baranov, A.V. (2014) Rol' etnopoliticheskikh mifov v konstruirovanii identichnosti kazachestva [The role of ethnopolitical myths in the design of the identity of the Cossacks]. Istoriya i sovremennost'. 1. pp. 69-86.

11. State Archive of the Russian Federation (GARF). Fund 10144. List 1. File 27. (In Russian).

12. Vedomosti SND i VS RF. (1992). 25 June. 25.

13. Sobranie aktov Prezidenta i Pravitel'stva RF. (1993). 12.

14. Supreme Council of the Russian Federation. (1993) Devyatyy (vneocherednoy) s"ezd narodnykh deputatov Rossiyskoy Federatsii. Byulleten'. № 3, 27 marta 1993 [Ninth (Extraordinary) Congress of People's Deputies of the Russian Federation. The Bulletin. No. 3, March 27, 1993]. Moscow: Izd. Verkhovnogo Soveta Rossiyskoy Federatsii.

15. State Archive of the Russian Federation (GARF). Fund 10121. List 1. File 121. (In Russian).

16. State Archive of the Russian Federation (GARF). Fund 10121. List 1. File 120. (In Russian).

17. Tabolina, T.V. (1999) Kazaki: drama vozrozhdeniya. 1980-1990-e gody [Cossacks: the drama of rebirth. 1980s-1990s]. Moscow: IEA RAS.

18. State Archive of the Russian Federation (GARF). Fund 10144. List 1. File 35. (In Russian).

19. State Archive of the Russian Federation (GARF). Fund 10144. List 1. File 36. (In Russian). 